\title{
Effects of Chitosan Isolated from Crab Exoskeleton on Postharvest Stem-end Rot Disease and on the Quality of Mango Fruit
}

\author{
Dewoowoogen P. Baclayon ${ }^{1}$ \\ and Candelario L. Calibo ${ }^{2}$
}

${ }^{1}$ Southern Leyte State University-Main Campus, Sogod, Southern Leyte, Philippines

${ }^{2}$ Department of Pure and Applied Chemistry, Visayas State University, Baybay City, Leyte 6521 - A, Philippines

\section{ABSTRACT}

Natural products for disease control and quality enhancement of fruit after harvest are increasingly used as alternative to chemical pesticides which are hazardous to human health and the environment. This study was conducted to extract chitosan from crab processing waste and compare its effect with commercial chitosan (Sigma) on stem-end rot disease and on the quality of carabao mango fruit. FT-IR spectra exhibited characteristic absorption bands of the amides, the amines and the carbonyl occurring as prominent and sharp peaks in both laboratory-produced and the commercial chitosan. In vitro assay of $D$. natalenses against chitosan showed comparable inhibitory effect on fungal growth and development with that of Dithane ('mancozeb'). When the extracted and commercial chitosan were dissolved in 2\% acetic acid and applied at 0-500 ppm, it was found that chitosan regardless of source and concentration can reduce weight loss in mango during storage. Dipping the fruits at different chitosan concentrations significantly reduced the infection rate of stem-end rot disease. The infection rate in fruits treated with 100 ppm laboratory-produced chitosan was comparable with that of 500 ppm Sigma chitosan. The results of this study suggest that the laboratory-produced chitosan at $100 \mathrm{ppm}$ is comparable with that of Sigma chitosan as they significantly slowed down the infection rate of stem end rot disease caused by D. natalensis. Chitosan's antimicrobial action and beneficial effects on fruit quality could have farreaching application in the fresh fruit industry.

Keywords: $\quad$ Biopesticide, chitosan, Colletotrichum gloeosporioides, Diplodia natalensis

Correspondence: D. P. Baclayon Address: Southern Leyte State University-Main Campus, Sogod, Southern Leyte, Philippines E-mail: dpbaclayon@yahoo.com.

DOI: 10.32945/atr3513.2013 


\section{INTRODUCTION}

Postharvest disease can be singled out as major cause of postharvest losses of perishable commodities as this will make the food commodity unappealing in the market and unfit for human consumption. For the past years, several efforts have been made to minimize postharvest losses due to diseases. For instance, pre-harvest and/or postharvest applications of chemical pesticides have been employed to highly perishable commodities. Considering the health and environmental hazards posed by these chemicals, there is a great demand for pesticide residue-free commodities. Thus, there is a world trend to explore alternatives that can minimize postharvest losses due to pathogenic diseases. These efforts can be geared towards the use of organic compounds that can reduce disease incidence without sacrificing human health and the environment.

Chitosan has been reported to possess antifungal and antibacterial properties (Hirano et al., 1990; El Mougy et al., 2002). It has attracted more attention because of its unique biological properties which include direct antimicrobial properties and its ability to be potent elicitors of plant defense reactions (Hadwiger et al., 1988) or systemic acquired resistance (Modina et al., 2009). It has been reported to inhibit the growth of a wide variety of bacteria (Sudarnshan et al., 1992; Yalpani et al., 1992) and fungi (Fang et al., 1994). Chitosan can be extracted from wide range of natural sources such as the exoskeleton of crustaceans, insects, fungi and some algae (Tolaimate et al., 2000). It is a modified carbohydrate polymer which has been used in medical and industrial products as a bioactive material (Cho et al., 2008; Matsuhashi \& Kume, 1997) and in agriculture to induce systemic resistance for the control of rice bacterial blight (Modina et al., 2009). This carbohydrate polymer is very reactive having three different functional groups (primary $-\mathrm{OH}$, secondary $-\mathrm{OH}$ and $-\mathrm{NH}_{2}$ ) and is soluble with organic acids (Stanford, 1989).

The Philippines as an archipelago is a rich source of shellfish waste where chitosan is obtained. For about a decade now, some studies have been conducted to explore chitosan's potentials. These however are limited especially that most of them were conducted on intact plants. There is a need to further explore its potential use in severed tissues like that of harvested produce as postharvest treatment. One of the highly perishable tropical fruit commodities with important commercial value is mango. Mango possesses a very short shelf life and reaches its maximum peak of ripening process on the $3^{\text {rd }}$ or $4^{\text {th }}$ day after harvest at ambient temperature 
(Narayana et al., 1996). Fruit sensitivity to decay and low storage temperature limit its potential long distance commercial transport (Hoa et al., 2002). In the Philippines, mango is considered as a major dollar earner agricultural commodity since this has been exported to temperate and semi-temperate countries. Importer countries however, are very particular of pesticide residues in fruit tissues. Thus, alternative postharvest treatment is very necessary. This study therefore attempts to explore the potentials of laboratory-produced chitosan as postharvest treatment on mango. It was conducted to: 1) characterize the chitosan extracted from crab exoskeleton and compare it with the commercial chitosan; 2) determine in vitro the antimicrobial effects of extracted and commercial chitosan against the stem-end rot pathogen of mango; and 3) compare the effects of extracted and commercial chitosan on stem-end rot development and on the quality of mango fruit.

\section{METHODOLOGY}

Extraction and preparation of chitosan solution. A two hundred-gram (200g) samples of crab exoskeletons was demineralized using 15\% (v/v) $\mathrm{HCl}$ in 1:10 solid/liquid ratio with constant stirring until no foam and bubbles appeared. After decanting the supernate containing the minerals, the residue was washed with distilled water. The residue was deproteinated with $5 \% \mathrm{NaOH}$ and the mixture was heated for $4 \mathrm{~h}$ at $70^{\circ} \mathrm{C}$ with constant stirring. The supernatant liquid was discarded and the residue was rinsed until neutral and oven dried at $40^{\circ} \mathrm{C}$ as chitin flakes. Chitin was treated with $50 \%(\mathrm{v} / \mathrm{v}) \mathrm{NaOH}$ in the deacetylation process. The mixture was heated for $8 \mathrm{~h}$ to hydrolyze the $\mathrm{N}$-acetyl linkages at $110^{\circ} \mathrm{C}$. Solubility tests were done to obtain the deacetylated product. Crude chitosan was washed, filtered and oven dried at $50^{\circ} \mathrm{C}$ for $24 \mathrm{~h}$. FT-IR spectra were determined in both chitosan samples. The extracted and commercial chitosan (Sigma) powder were dissolved in $2 \%$ acetic acid. Different concentrations of chitosan solution were prepared from the $1000 \mathrm{ppm}$ stock solution: (100-500 ppm).

Isolation and preparation of stem-end rot pathogens. Mango fruit infected with stem end rot caused by $D$. natalensis were brought to the laboratory. Infected tissues of about $3-5 \mathrm{~mm}^{2}$ were cut aseptically and placed in Petri plate containing potato dextrose agar (PDA). After two days of incubation, fungal mycelia were cut and transferred to another PDA plate 
to purify the culture. Some mycelial discs were kept in PDA slants as stock culture.

In vitro assay of chitosan against the stem-end rot pathogen of mango. Fifteen $\mathrm{mL}$ of melted PDA was poured in each Petri plate. After cooling, a 5mm paper disc which was previously immersed in different chitosan concentrations (100-500 ppm) was blot-dried and placed at the center. As controls, the commercial fungicide Dithane (following the manufacturer's recommended rate) and $2 \%$ acetic acid were included. Four mycelial discs of $5 \mathrm{~mm}$ in diameter were inoculated equidistantly to the paper disc. The plates were incubated at room temperature. The inhibition zone from disc was measured at 2, 4 and 6 days after treatment.

Chitosan application on mango fruits. Fully ripe mango (var. Carabao) fruits were procured from a farmer's commercial field and sorted based on uniformity in size, weight, maturity and free from defects. Five fruit samples per replicate were used. The fruits were disinfected with $2 \%$ sodium hypochlorite for $2 \mathrm{~min}$, washed several times with sterile distilled water and air dried. Five pin-pricks were made near the peduncle using a sterile needle. The samples were then dipped for one minute in chitosan solution at different concentrations (100-500 ppm) and kept at room temperature. Fruits dipped in distilled water served as control. After 30 min, the fruits were applied with $D$. natalensis inoculum by spraying at the pin-pricked portions.

The inoculum was prepared by adding 3-4 $\mathrm{mL}$ of sterile distilled water into the PDA plates with mass produced $D$. natalensis and scraping with sterile glass rod to remove it from the media. Spores were filtered through 4 layers of sterile cotton cloth. The spore suspension was standardized to $1 \times 10^{5} \mathrm{cfu} / \mathrm{mL}$ by dilution plating method.

The fruits were stored at ambient conditions and after 7 days they were assessed based on the number of infected fruits expressed in percentage, weight of infected tissues per fruit in percentage and weight loss as percentage of the initial weight.

Experimental design and data analysis. The experiment was laid out in completely randomized design with three replications with 5 sample fruits per replicate. The data was subjected to analysis of variance and least significant difference test to compare the differences between treatment means. 


\section{RESULTS AND DISCUSSION}

Chemical property of extracted crab chitosan. Functional group analyses by Fourier transform-infrared (FT-IR) spectroscopy had verified chitosan properties produced in the laboratory run with Sigma AR chitosan as standard (Fig. 1 and Table 1). These data suggest that chemical property of laboratory-produced chitosan is comparable with that of Sigma chitosan already available in the market.

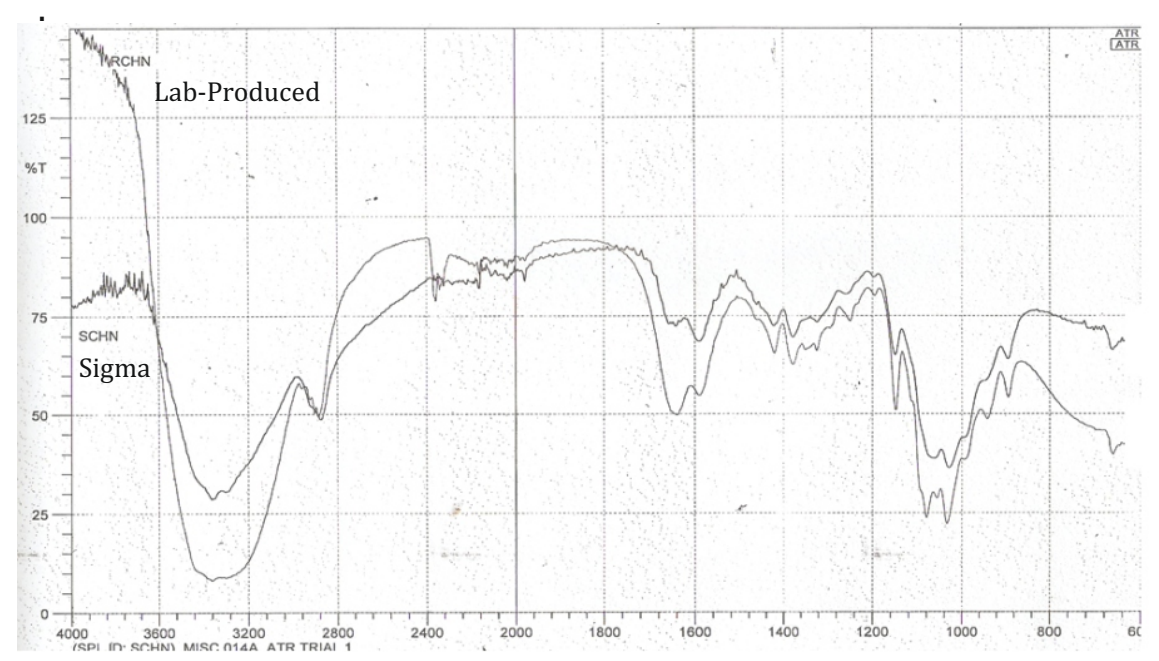

Figure 1. Fourier transform-infrared (FT-IR) spectroscopy of extracted and commercial (Sigma) chitosan.

Table 1. Functional group found in laboratory-produced chitosan corresponding to the wave number in FT-IR (shown in Fig. 1).

\begin{tabular}{lll}
\hline Biopolymer & Wave number, $\mathrm{v}\left(\mathrm{cm}^{-1}\right)$ & Functional group \\
\hline Standard chitosan & 1650 (sharp) & -N-H bending \\
(Sigma-Aldrich) & 2900 (sharp) & $-\mathrm{C}-\mathrm{H}$ stretching \\
& 3450 (strong, broad) & -N-H stretching \\
Laboratoy-produced & 1600 (sharp) & $-\mathrm{N}-\mathrm{H}$ bending \\
chitosan & 2900 (sharp) & $-\mathrm{C}-\mathrm{H}$ stretching \\
& 3450 (sharp, broad) & $-\mathrm{N}-\mathrm{H}$ stretching \\
\hline
\end{tabular}

In vitro assay of D. natalensis against chitosan. Bioassay of D. natalensis against different levels of chitosan revealed that although at varying rates, both laboratory-produced and Sigma chitosan inhibited growth of the fungus (Fig. 2). 
It was observed that growth inhibition in plates with Sigma chitosan was comparable with that of the positive control-Dithane ('mancozeb'). However, in plates with laboratory-produced chitosan, growth inhibition is inferior with that of Sigma. Inhibition zone in plates with acetic acid, on the other hand, was practically nil. These results imply that chitosan has direct inhibitory effects on the growth of fungi. It has been reported that chitosan exerts inhibitory action on hyphal growth and spore germination of numerous pathogenic fungi (Hadwiger \& Beckman, 1980). It is possible that there was morphological distortion of important fungal structure of $D$. natalensis. However, there is a need to validate this claim as there was no morphological examination conducted in this study. Other data would strengthen our claim on morphological distortion considering that excessive mycelial branching, abnormal shapes, swelling, hyphae size reduction (Benhamou, 1992; El Ghaouth et al., 1992; Cheah et al., 1997), large vesicles or empty cells devoid of cytoplasm in the mycelium (El Hassai, 2004) have been observed in most important pathogenic fungi. The result of this bioassay suggests that chitosan has multi action in prolonging the shelf life of perishable commodities. It can act to elicit resistance of living tissues to invading fungus and/or distort normal growth of pathogenic fungi.

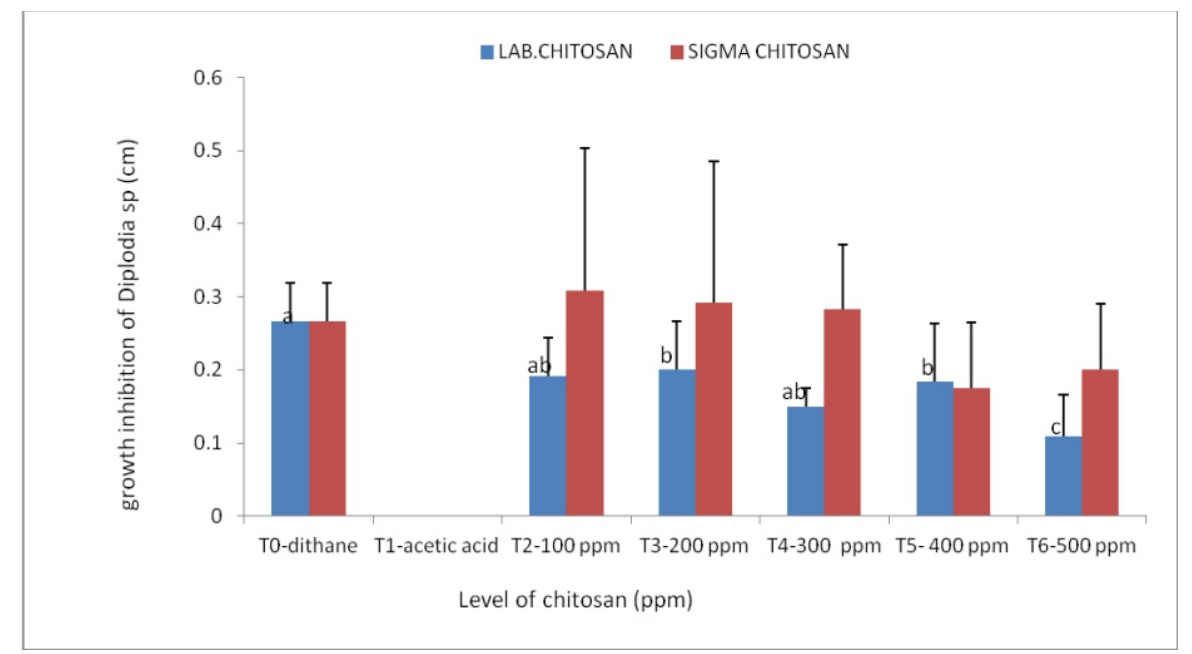

Figure 2. In vitro growth inhibition of D. natalensis treated with different levels of chitosan after 6 days of incubation. 
Postharvest quality of ripe mango fruit applied with chitosan. Dipping the fruits at different chitosan concentrations significantly reduced the percent infection of stem-end rot disease (Fig. 3). Even at the lowest concentration of $100 \mathrm{ppm}$, chitosan was effective in slowing down the growth of $D$. natalensis, the organism that causes stem-end rot disease. The infection rate in fruits treated with lab-produced chitosan was comparable with that of Sigma chitosan at $500 \mathrm{ppm}$. When D. natalensis infected tissue was taken from the fruit, it can be noted that about $25 \%$ of the tissue was infected by stem-end rot in the control fruits (Fig. 4). Except for fruit treated with $200 \mathrm{ppm}$, the rest had very minimal rotten tissue due to $D$. natalensis. Although there were fruits that showed infection, the disease did not consume the pulp portion of the fruits. The reduction of infection rate by $D$. natalensis can be explained in a number of mechanisms. Chitosan may induce the defense enzyme (Mauch et al., 1984) like chitinase (El-Ghaouth et al., 2006), which slowed down the growth of D. natalensis on the fruits. Bautista-Banos et al. (2006) also reported that due to its filmogenic property, chitosan may also act as a barrier to the outward flux of nutrients and limits the availability of nutrients to a level that will not sustain growth of the pathogens. In this study, the growth of $D$. natalensis was retarded as exhibited by the slow progress of infection on the pricked portion to the fruit pulp. This can be further supported by the findings of ElGhaouth et al. (2006) that fungal cells exposed to chitosan exhibited signs of nutrient deprivation. Furthermore, there is evidence that exposure of plant tissues to chitosan favored lignification process (Pearce \& Ride, 1982) and could mediate the expression of resistance genes that produce callus and phytoalexin thereby restricting fungal penetration.

Both laboratory-produced crab chitosan and commercially available chitosan (Sigma) showed significant reduction in weight loss regardless of chitosan source and concentration (Fig. 5). It can be noted that weight loss was remarkably low in fruits treated with different levels of chitosan except for the fruits applied with 400 ppm Sigma chitosan in which weight loss was higher than the control fruits. The reduction in weight loss could be attributed to the chitosan molecules which filled up spaces in the epidermal tissues of the fruit that served as transpiratory exit of water. This claim can be supported by the findings of Abbasi et al. (2009) that minimum weight loss was observed in fruit treated with irradiated chitosan extracted from crab. They suggested that chitosan acted as barrier between inner and outer environments. It can be further suggested that, although respiration rate was not measured in this study, degradation of 


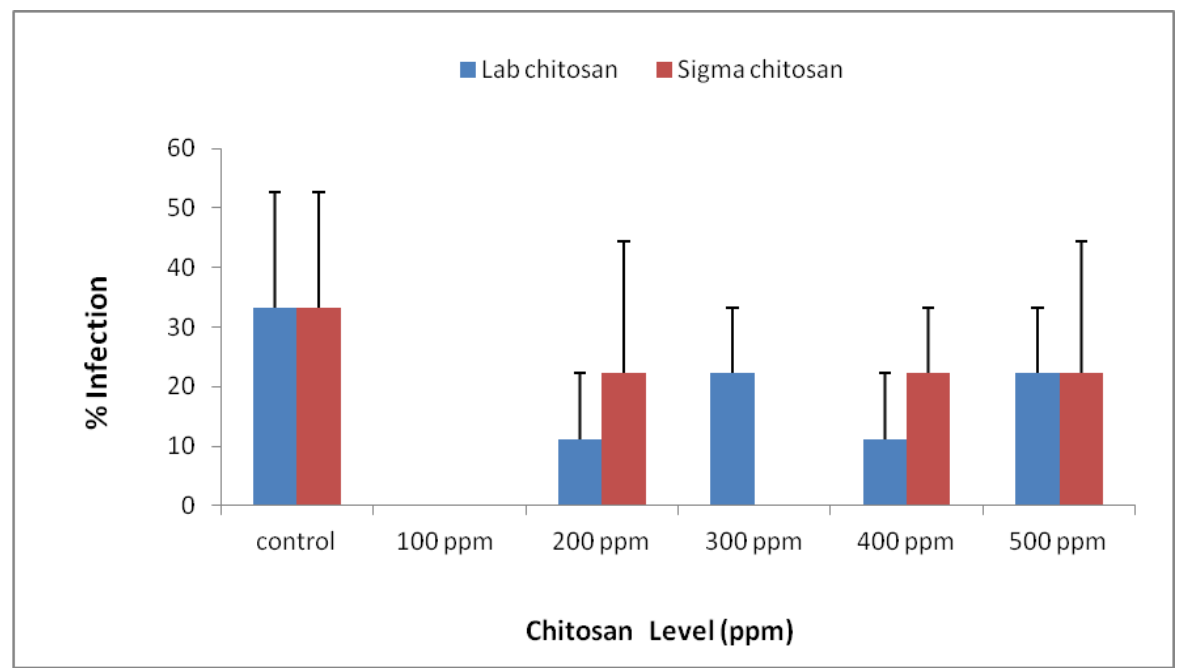

Figure 3. Percent fruit infection of mango fruit treated with different levels of chitosan during the 7-day storage period.

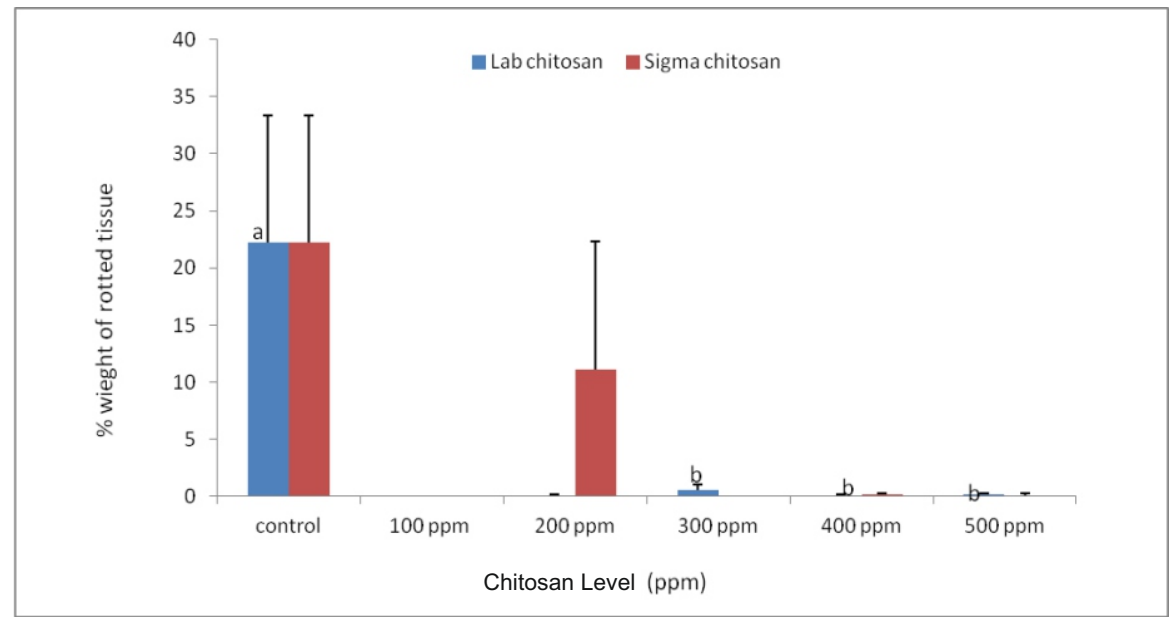

Figure 4. Percent rotted tissue of mango fruit treated with different levels of chitosan during the 7-day storage period. 


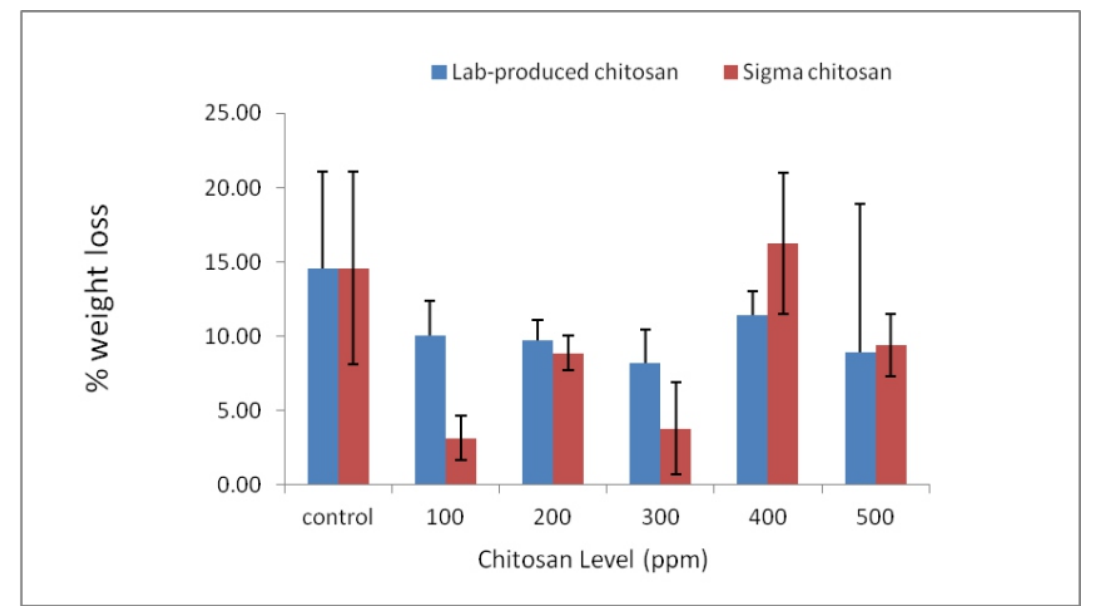

Figure 5. Percent weight loss of mango fruit treated with different levels of chitosan during the 7-day storage period.

respiratory substrate and other deteriorative processes could be minimal in fruit treated with chitosan, hence maintaining fruit quality for longer time. The extremely high weight loss in fruit treated with $400 \mathrm{ppm}$ was due to the severe disease infection by postharvest pathogens other than $D$. natalensis in the fruits causing rapid decline in weight. The fruits in this treatment exhibited blackening and depression of the peel and pulp which is a manifestation of anthracnose disease (data not presented). This result may suggest that chitosan at this concentration can only reduce $D$. natalensis infection but not much on other pathogens e.g. Colletotrichum gloeosporioides.

\section{CONCLUSION AND RECOMMENDATIONS}

FT-IR spectra of laboratory-produced crab chitosan exhibited characteristic absorption bands of the amides, the amines and the carbonyl occurring as prominent and sharp peaks as that of the commercial chitosan. These chemical properties of extracted crab chitosan corroborated standard positive tests for chitosan as a biopolymer. In vitro fungal development showed direct effect of chitosan on D. natalensis. This result indicates the multi-action of chitosan in counteracting pathogens: both by eliciting resistance on host tissues and directly inhibiting growth of pathogenic fungi. Moreover, chitosan has potential for use as postharvest 
biopesticide as it extends shelf life of mango fruit by slowing down the rate of fungal infection on pricked tissues and reducing weight loss . Laboratoryproduced crab chitosan at $100 \mathrm{ppm}$ is comparable with that of Sigma chitosan as they significantly slowed down the infection rate of stem end rot disease caused by D. natalensis. Concentrations of lower than $100 \mathrm{ppm}$ in combination with different concentrations of acetic acid can also be tested to determine the minimum effective levels and combinations to control other important postharvest diseases. Further study on compositional analysis is important to evaluate whether chitosan has an effect on the nutrients, texture and other characteristics of the mango fruit.

\section{ACKNOWLEDGEMENT}

This work was carried out with the financial support of the Commission on Higher Education, Republic of the Philippines.

\section{REFERENCES}

ABBASI, N.A., Z. IQBAL, M. MAQBOOL, and I.A. HAFIZ. 2009. Postaharvest quality of mango (Mangifera indica L.) fruit as affected by chitosan coating. Pak. J. Bot., 41(1): 343-357.

BAUTISTA-BANOS S., A.N. HERNANDEZ-LAUZARDO, M.G., VELASQUEZ-DEL VALLE M. HERNANDEZ-LOPEZ, E. AITH BARKA, E. BOSQUEZ-MOLINA and C.L. WILSON. 2006. Chitosan as a potential natural compound to control pre and post harvest disease of horticultural commodities. Crop Protection. 25:108-118.

BAUTISTA-BANOS, S., M. HERNANDEZ-LOPEZ, E. BOSQUEZ-MOLINA and C.L. WILSON. 2003. Effects of chitosan and plant extracts on growth of Colletotrichum gloeosporiodes, anthacnose levels and quality of papaya fruit. Crop Prot. 22: 1087-1092.

BENHAMOU, N. 1992. Ultrastractural and cytochemical aspects of chitosan on Fusarium oxysporum f. sp. radicis- lycopersici,agent of tomato crown and root rot. Phytopathology 82: 1185-1193.

CHEAH, L.H., B.B.C. PAGE and R. SHEPERD. 1997.Chitosan coating for inhibition of sclerotina carrots. N.Z.J. Crop Hort.Sci. 25: 89-92. 
CHO, M.H., H.K. NO and PRINYAWIWATKUL. 2008. Chitosan treatments effect growth and selected quality of sunflower sprouts. J. Food Sci., 73 (1): 70-77.

EL GHAOUTH, A., R. PONNAMPALAM, F. CASTAIGNE and J. ARUL. 1992. Chitosan coating to extend the storage life of tomatoes. Hort Science 27: 1016-1018.

EL GHAOUTH, A., J. ARUL, J. GRENIER and A. ASSELIN. 1992. Antifungal activity of chitosan on two postharvest pathogen of strawberry fruits. Phytopathology. 82: 398-402.

EL HASSAI, M., A. EL HADRAMI, F. DAAYF, M. CHERIF, E. AIT BARKAL and I. EL HADRAMI. 2004. Chitosan, antifungal product against Fusarium oxysporum f. sp. albedinis and elicitor of defense reactions in date palm roots. Phytopathol. Mediterr. 43:195-204.

EL MOUGY, N., S. ABB-EL-KAREM and M.A. ABB-ALLA. 2002. Post harvest disease control: Preventive effect of chitosan and bioagents against green and gray moulds of apple fruits. Egypt J. Phytopathol. 30:99-113.

FANG, S.W., C.F. LI and D.Y.C. SHIH. 1994. Antifungal activity of chitosan and its perspective effect on low-sugar candied kumquat. J. Food Prot., 56: 136-140.

HADWIGER LA, C. CHIANG, S. VICTORY and D. HOROVITZ. 1988. The molecular biology of chitosan in plant-pathogen interactions and its application to agriculture. Chitin and chitosan: sources, chemistry, biochemistry, physical properties and applications. Elsevier Applied Sciences, Amsterdam, pp 119-138.

HADWIGER, L.A. and J.M. BECKMAN 1980. Chitosan as a component of peaFusarium solani interactions. Plant Physiol. 66: 205-211.

HIRANO, S, C. ITAKURA, H. SEINO, Y. AKIYAMA, I. NOTALA, N. KANBARA and N. KAWAKAMI. 1990. Chitosan as an ingredient for domestic animal feeds. J. Agric. Food Chem. 38:1214-1217. 
HOA, T.T., M.N. DUAMP, M. LEBRUM and E.A. BALDWIN. 2002. Effect of different coating treatments on the quality of mango fruit. J. Food Qlty.pp. 25:471-486.

MATSUHASHI, S. and T. KUME. 1997. Enhancement of microbial activity of chitosan by irradiation. J. Sci. Food Agric. 73: 237-241.

MODINA, I., C. L. CALIBO and L. M. BORINES. 2007. Antimicrobial property of chitosan and induction of systemic acquired resistance for the control of rice bacterial blight caused by Xanthomonas oryzae $p v$. oryzae (Swings et al.). Annals of Tropical Research 31:69-90.

MAUCH, F., L.A. HADWIGER and T. BOLLER. 1984. Ethylene symptoms not signal for induction of chitinase and beta-1,3-glucanase in pea pods by pathogens and elicitors. Plant Physiol. 76: 607-611.

NARAYANA, C.K., R.K. PAL, and S.K. ROY. 1996. Effect of pre-storage treatments and temperature regimes on shelf-life and respiratory behavior of ripe Baneshan mango. I. Food Sci. Tech., 33:79-82.

STANFORD, P.A. 1989. Chitosan: commercial uses and potential applications. In: Chitin and chitosan-sources, chemistry, biochemistry, physical properties and applications. (Eds.): SkjakBraek, G., T. Anthonsen, P. Sanford. London: Elsevier. pp 51-70.

SUDARSHAN, N.R., D.G. HOOVER and D. KNORR. 1992. Antimicrobial action of chitosan. Food Biotechnol. 6(3): 257-272.

TOLAIMATE, A., J. DESBRIERES, M. RHAZI, M. ALAGUI, M. VINCENDON and P. VOTTERO. 2000. The influence of deacetylation process on the physicochemical characteristics of chitosan from squid chitin. Polymer., 41: 2463-24639.

YALPANI, M., F. JOHNSON AND L.E. ROBINSONS. 1992. Advances in chitin and chitosan. London: Elsevier Applied Sciences. p. 543. 